\title{
Analysis of nucleotide insertion opposite urea and translesion synthesis across urea by DNA polymerases
}

\author{
Taishu Kawada ${ }^{1}$, Katsuhito Kino ${ }^{1 *}$, Kyousuke Tokorodani ${ }^{1}$, Ryuto Anabuki ${ }^{1}$, Masayuki Morikawa', \\ Takanobu Kobayashi', Kazuaki Ohara', Takayuki Ohshima² and Hiroshi Miyazawa ${ }^{1}$
}

\begin{abstract}
Urea (Ua) is produced in DNA as the result of oxidative damage to thymine and guanine. It was previously reported that Klenow fragment (Kf) exo ${ }^{-}$incorporated dATP opposite Ua, and that DNA polymerase $\beta$ was blocked by Ua. We report here the following nucleotide incorporations opposite Ua by various DNA polymerases: DNA polymerase a, dATP and dGTP (dATP > dGTP); DNA polymerase $\delta$, dATP; DNA polymerase $\zeta$, dATP; Kf exo-' dATP; Sulfolobus solfataricus P2 DNA polymerase IV (Dpo4), dGTP and dATP (dGTP > dATP); and DNA polymerase $\eta, d$ CTP, dGTP, $d A T P$, and dTTP (dCTP $>d G T P>d A T P>d T T P$ ). DNA polymerases $\beta$ and $\varepsilon$ were blocked by Ua. Elongation by DNA polymerases $\delta$ and $\zeta$ stopped after inserting dATP opposite Ua. Importantly, the elongation efficiency to full-length beyond Ua using DNA polymerase $\eta$ and Dpo4 were almost the same as that of natural DNA.
\end{abstract}

Keywords: Oxidative DNA damage, Urea, DNA polymerase, Base pair, Nucleotide incorporation, Elongation

\section{Introduction}

DNA damage is a major cause of cell death, mutations, cancer, neurological disease, and aging. Urea (Ua) is produced in DNA by ionizing radiation [1] due to oxidative damage to thymine [2-7] and guanine [8, 9] (Fig. 1). Although $\mathrm{Ua}$ is reportedly repaired by many enzymes $[3,5$, $10-24]$, to date there have been only a few investigations into nucleotide incorporation and/or elongation past Ua by DNA polymerases, such as the blockage by Ua of DNA replication by T4 DNA polymerase [4, 25, 26], Klenow fragment (Kf) [4, 25-28], DNA polymerase I [25], human DNA polymerase $\beta$ [28], Sequenase 2.0 [28], and AMV reverse transcriptase [28]. However, nucleotide incorporations opposite $\mathrm{Ua}$ and translesion synthesis across Ua by DNA polymerases $\alpha, \delta, \varepsilon, \eta, \zeta$ and Sulfolobus solfataricus P2 DNA polymerase IV (Dpo4) have not

\footnotetext{
* Correspondence: kkino@kph.bunri-u.ac.jp

'Kagawa School of Pharmaceutical Sciences, Tokushima Bunri University, 1314-1 Shido, Sanuki, Kagawa 769-2193, Japan

Full list of author information is available at the end of the article
}

been analyzed to date. Herein, we describe our studies of nucleotide incorporations and translesion synthesis in relation to Ua with DNA polymerases $\alpha, \delta, \varepsilon, \eta, \zeta$ and Dpo4. Also, we confirmed nucleotide incorporation and extension in relation to $\mathrm{Ua}$ using $\mathrm{Kf} \mathrm{exo}^{-}$and DNA polymerase $\beta$.

\section{Materials and methods Enzymes}

T4 polynucleotide kinase was purchased from New England Biolabs (Ipswich, USA). T4 DNA ligase was purchased from Takara (Otsu, Japan). Calf thymus DNA polymerase $\alpha$ and human DNA polymerase $\beta$ were purchased from Chimerx (Milwaukee, USA). Klenow fragment exonuclease ${ }^{-}$was purchased from Fermentas (Waltham, USA). Yeast DNA polymerase $\zeta$ was purchased from Enzymax (Lexington, USA). Human DNA polymerase $\delta$ [29], human DNA polymerase $\eta$ [30], and Saccharomyces cerevisiae DNA polymerase $\varepsilon$ [31] were purified as described previously. Dpo4 was purchased from Trevigen (Gaithersburg, USA). 
<smiles>[R]NC(=O)NC(=O)C(=O)O</smiles>

\section{DNA substrates}

The DNA template $\left(5^{\prime}\right.$-CTCATCAACATCTTXAATTCACAATCAATA-3', X represents guanine), Alexa 680labeled 15-mer primer (5'-Alexa680-TATTGATTGTGA ATT-3'), 6-mer oligonucleotide containing 8oxoG (5'CTT8oxoGAA-3'), 13-mer oligonucleotide (5'-TTCA CAATCAATA-3'), and 11-mer oligonucleotide (5' CTCATCAACAT-3') were constructed by Japan Bio Services Co., Ltd. (Saitama, Japan).

The 30-mer DNA template containing Ua (30-merUa) (5' CTCATCAACATCTTXAATTCACAATCAATA-3', where $\mathrm{X}$ represents $\mathrm{Ua}$ ) was constructed as follows. A 6-mer oligonucleotide containing 8oxoG (5'-CTT8oxoGAA-3') was oxidized to a 6-mer oligonucleotide containing oxaluric acid (Oxa) using $\mathrm{I}_{2}$ and $\mathrm{KI}$ [32], then Oxa was hydrolyzed to provide a 6-mer oligonucleotide containing Ua (6-merUa) (5' CTTXAA-3', where X represents Ua) [9]. This 6-merUa and a 13-mer oligonucleotide (5'-TTCACAATCAATA-3') were phosphorylated by $\mathrm{T} 4$ polynucleotide kinase. The 30-merUa was prepared by ligation of an 11-mer oligonucleotide ( $5^{\prime}$ CTCATCAACAT-3') to the $5^{\prime}$ side of the 6-merUa and the phosphorylated 13-mer oligonucleotide to the 3 ' side of the 6-merUa using T4 DNA ligase, using a 30-mer DNA-RNA chimeric oligonucleotide (5'-TATTGATTgTGAATTGCAGATgTTGATGAG-3', where g represents guanosine, not deoxyguanosine) as a template. 30-merUa was isolated by HPLC (Fig. S1).

\section{Polymerization reaction}

Polymerization reactions $(5 \mu \mathrm{L})$ were carried out using the following mixtures: (for DNA polymerase $\alpha$ ) $40 \mathrm{mM}$ Tris- $\mathrm{HCl}$ (pH 8.0), $5 \mathrm{mM} \mathrm{MgCl}, 10 \mathrm{mM} \mathrm{NaCl}, 45 \mathrm{mM}$ $\mathrm{KCl}, 1 \mathrm{mM}$ DTT, $100 \mu \mathrm{g} / \mathrm{mL}$ bovine serum albumin (BSA); (for DNA polymerase $\beta$ ) $50 \mathrm{mM}$ Tris- $\mathrm{HCl}(\mathrm{pH}$ 8.8), $10 \mathrm{mM} \mathrm{MgCl}_{2}, 1 \mathrm{mM}$ DTT, $100 \mu \mathrm{g} / \mathrm{mL} \mathrm{BSA}$; (for DNA polymerase $\delta) 50 \mathrm{mM}$ Tris- $\mathrm{HCl}(\mathrm{pH} 7.4), 2 \mathrm{mM}$ $\mathrm{MgCl}_{2}, 2 \mathrm{mM}$ DTT, $100 \mu \mathrm{g} / \mathrm{mL}$ BSA; (for DNA polymerase $\varepsilon$ ) $50 \mathrm{mM}$ Tris- $\mathrm{HCl}$ (pH 7.4), $8 \mathrm{mM} \mathrm{MgCl}_{2}, 2 \mathrm{mM}$ DTT, $100 \mu \mathrm{g} / \mathrm{mL} \mathrm{BSA}$; (for DNA polymerases $\zeta$ and $\eta$ ) $50 \mathrm{mM}$ Tris- $\mathrm{HCl}$ (pH 8.0), $2 \mathrm{mM} \mathrm{MgCl}_{2}, 5 \mathrm{mM}$ DTT, $100 \mu \mathrm{g} / \mathrm{mL} \mathrm{BSA}$ (for $\mathrm{Kf} \mathrm{exo}^{-}$) $50 \mathrm{mM}$ Tris- $\mathrm{HCl}$ (pH 8.0), $5 \mathrm{mM} \mathrm{MgCl} 2,1 \mathrm{mM} \mathrm{DTT}, 100 \mu \mathrm{g} / \mathrm{mL} \mathrm{BSA}$; (for Dpo4) $20 \mathrm{mM}$ HEPES (pH 6.5), $10 \mathrm{mM} \mathrm{MgCl}_{2}, 1 \mathrm{mM} \mathrm{MnCl}_{2}$ $100 \mathrm{mM} \mathrm{NaCl}, 100 \mu \mathrm{g} / \mathrm{mL}$ BSA.

The reaction mixtures for DNA polymerases $\alpha, \beta, \delta, \varepsilon$, $\eta, \zeta, \mathrm{Kf} \mathrm{exo}^{-}$and Dpo4 contained $100 \mathrm{fmol}$ of the template and $50 \mathrm{fmol}$ of 5 '-Alexa680-labeled 15-mer primer. Other conditions and the concentrations of dNTPs and DNA polymerases are specified in the figure legends. Reactions were performed at $30^{\circ} \mathrm{C}$ for $30 \mathrm{~min}$ for DNA polymerases $\alpha, \beta, \delta, \varepsilon, \zeta, \mathrm{Kf}$ exo $^{-}$and Dpo4, and at $37^{\circ} \mathrm{C}$ for $30 \mathrm{~min}$ for DNA polymerase $\eta$. All reactions were stopped by adding $5 \mu \mathrm{L}$ of stop buffer (15 mM EDTA, $10 \%$ glycerol $(\mathrm{v} / \mathrm{v})$, and $100 \mu \mathrm{M}$ rhodamine $6 \mathrm{G})$. Aliquots $(2.5 \mu \mathrm{L})$ were subjected to electrophoresis in a denaturing $16 \%$ polyacrylamide $(\mathrm{v} /$ 
v) gel containing $8 \mathrm{M}$ urea at $30 \mathrm{~W}$ for $90 \mathrm{~min}$. The fluorescence intensity of each n-mer band $\left(I_{n}\right)$ was quantified using an Odyssey infrared imaging system from LI-COR (Lincoln, USA) for 5'-Alexa 680-labeled products. The nucleotide incorporation efficiency was calculated using the formula: $\sum I_{\mathrm{n}}(n \geq 16) / \sum I_{\mathrm{n}}(n \geq 15)$. The DNA synthesis efficiency was calculated using the formula: $I_{30} / \sum I_{\mathrm{n}}$ $(n \geq 15)$.

\section{Results}

Incorporation and translesion synthesis opposite Ua by DNA polymerases $\alpha, \beta, \delta, \varepsilon$ and $\mathrm{Kf}$ exo ${ }^{-}$

DNA polymerase $\alpha$ was used for in vitro nucleotide insertion and the analysis of primer extension of template oligonucleotides containing Ua. Under the reaction condition in which DNA polymerase $\alpha$ inserted only dCTP opposite guanine (Fig. 2A, lanes 1-4), dATP and dGTP were inserted opposite $\mathrm{Ua}$, and dTTP and dCTP were not inserted (Fig. 2A, lanes 6-9). Lane 6 of Fig. 2A shows that one or more dATP nucleotides were inserted, with a nucleotide incorporation ratio of $21 \%$. The yield of dGTP insertion opposite Ua was 6\% (Fig. 2A, lane 8).
These results show that dATP, and not dGTP, was predominantly inserted opposite Ua by DNA polymerase $\alpha$.

We investigated whether DNA polymerase $\alpha$ extends the primer beyond Ua. DNA polymerase $\alpha$ slightly elongated the 15 -mer primer to 30 -mer (3\%) across the Ua lesion (Fig. 2A, lane 10), although the primer extension across Ua was of low efficiency as compared with primer extension across guanine (87\%) (Fig. 2A, lanes 5 and 10).

DNA polymerase $\beta$ could not insert any nucleotide opposite Ua under the condition that accurately inserted dCTP opposite guanine (Fig. 2B, lanes 1-4 and 6-9). On the one hand, $\mathrm{Kf}$ exo $^{-}$inserted dATP opposite $\mathrm{Ua}$, whereas dTTP, dGTP, and dCTP were not inserted (Fig. 2C, lanes 6-9) under the condition that inserted only dCTP opposite guanine (Fig. 2C, lanes 1-4). Thus, Kf exo ${ }^{-}$incorporated one nucleotide, then further incorporations were largely stalled (Fig. 2D, lane 10, and Fig. S2).

DNA polymerase $\delta$ inserted only dATP (7\%) opposite Ua under the condition that incorporated only dCTP into guanine in the template (Fig. 3A, lane 7, and Fig. $3 \mathrm{~B}$, lane 7$)$. In contrast, DNA polymerase $\varepsilon$ did not insert any nucleotide (Fig. 3C, lanes 6-9). DNA polymerase $\delta$

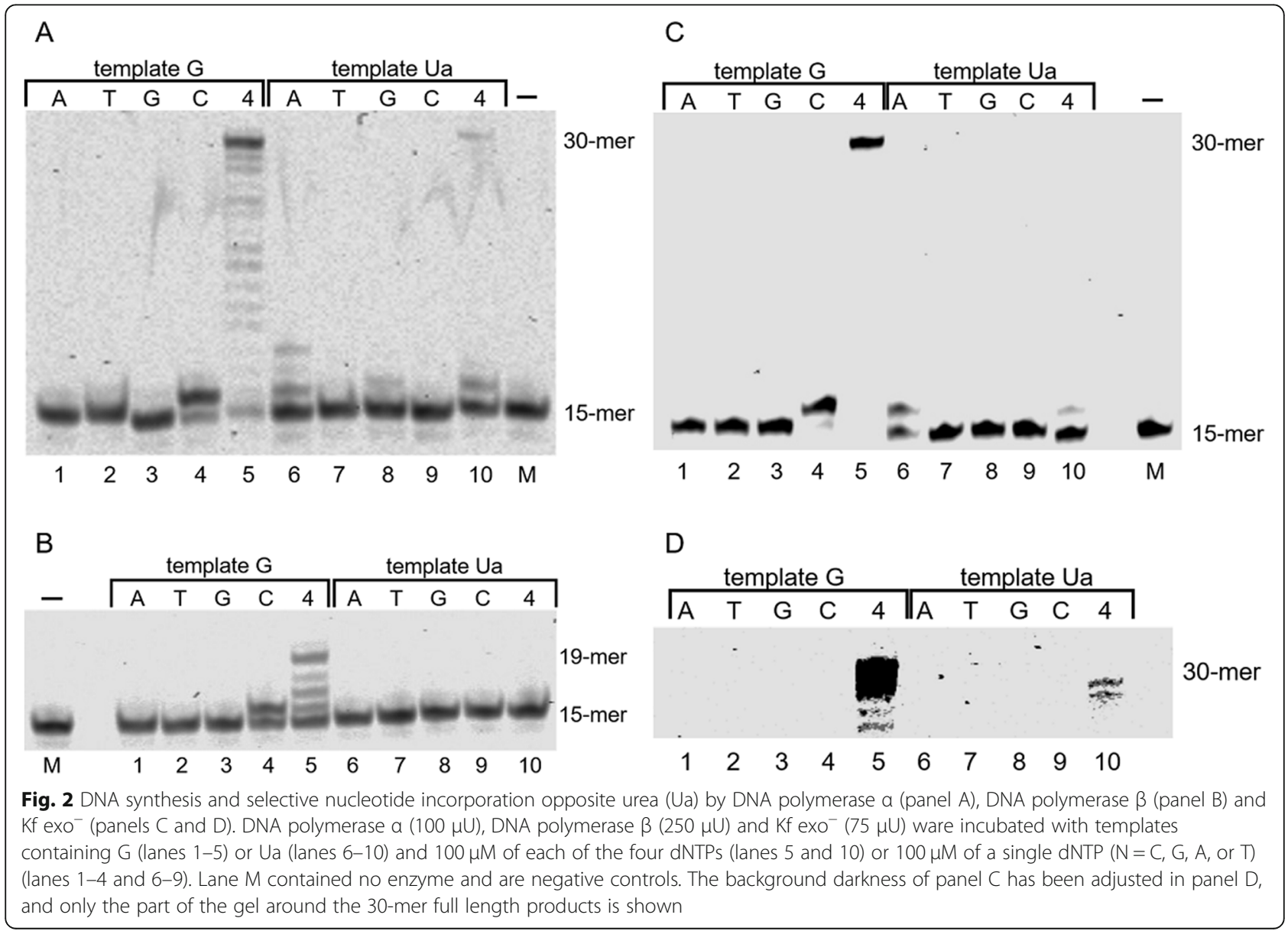




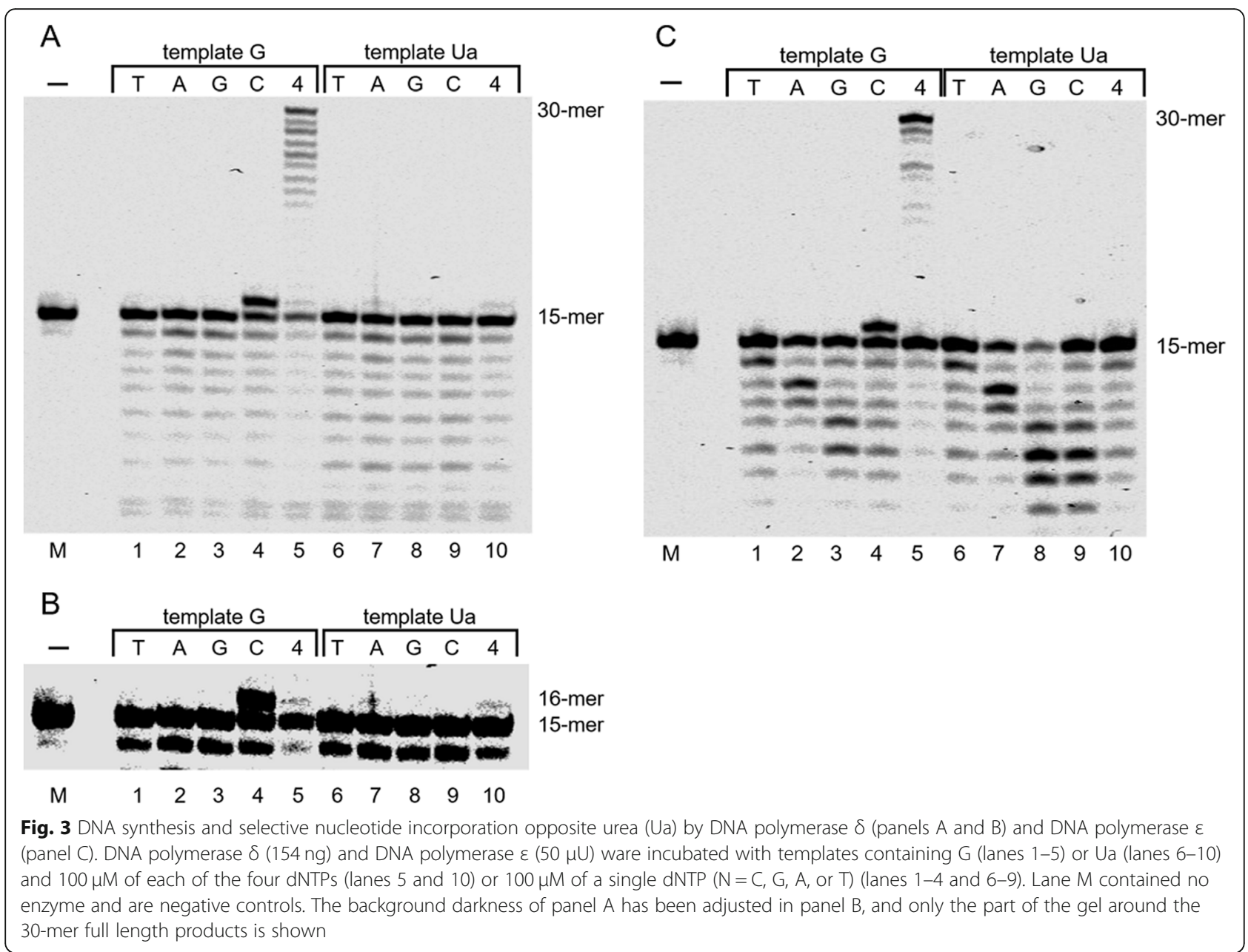

did not elongate the 15-mer primer after dATP was inserted opposite Ua, and DNA polymerase $\varepsilon$ did not elongate the primer even in the presence of all four dNTPs.

\section{Incorporation and translesion synthesis opposite Ua by translesion synthesis DNA polymerases}

DNA polymerase $\zeta$ predominantly inserted mainly dATP (3\%) opposite Ua (Fig. 4A, lane 7) but no fulllength extension across $\mathrm{Ua}$ was detected (Fig. 4A, lane 10). DNA polymerase $\eta$ efficiently elongated the primer up to full-length past Ua (Fig. 4B, lane 10, and Fig. S3) and incorporated dCTP (25\%), dGTP (21\%), dATP (15\%), or dTTP (10\%) opposite Ua (Fig. 4B, lanes 6-9). Dpo4 inserted dGTP (16\%) and dATP (14\%) opposite Ua (Fig. 4C lanes 6-9) under the condition that inserted mainly dCTP opposite guanine (Fig. 4C lanes 1-4), and could elongate the primer across Ua, although the elongation efficiency beyond Ua was slightly inferior to that across guanine (Fig. 4C lanes 5 and 10).

\section{Discussion}

In previous reports, DNA synthesis across Ua and nucleotide incorporation opposite Ua was analyzed using DNA polymerase $\beta$ and $\mathrm{Kf}^{-\mathrm{exo}^{-}}[25,28]$. Here, using DNA polymerase $\beta$ and $\mathrm{Kf}^{-\mathrm{exo}^{-}}$, we re-analyzed nucleotide incorporation and translesion synthesis opposite Ua. The results of elongation efficiency by DNA polymerase $\beta$ beyond $\mathrm{Ua}$ (Fig. $2 \mathrm{~B}$ ) confirm that $\mathrm{Ua}$ is an impediment to DNA synthesis [28].

Escherichia coli DNA polymerase I lacking $3^{\prime} \rightarrow 5^{\prime}$ exonuclease activity was previously shown to insert guanine and adenine opposite Ua [25]. In addition, it was reported that adenine is incorporated preferentially opposite Ua compared with guanine [28]. The present results (Fig. 2C) are in good agreement with previous reports.

DNA polymerases $\alpha, \delta$ and $\varepsilon$ are replicative DNA polymerases belonging to the B-family. DNA polymerase $\alpha$ is associated with DNA primase and is an enzyme that can initiate DNA synthesis. In our results, DNA polymerase $\alpha$ inserted dATP, but primer extension by DNA polymerase $\alpha$ beyond Ua was of low efficiency (Fig. 2A). Hence, DNA polymerase $\alpha$ does not actively participate 


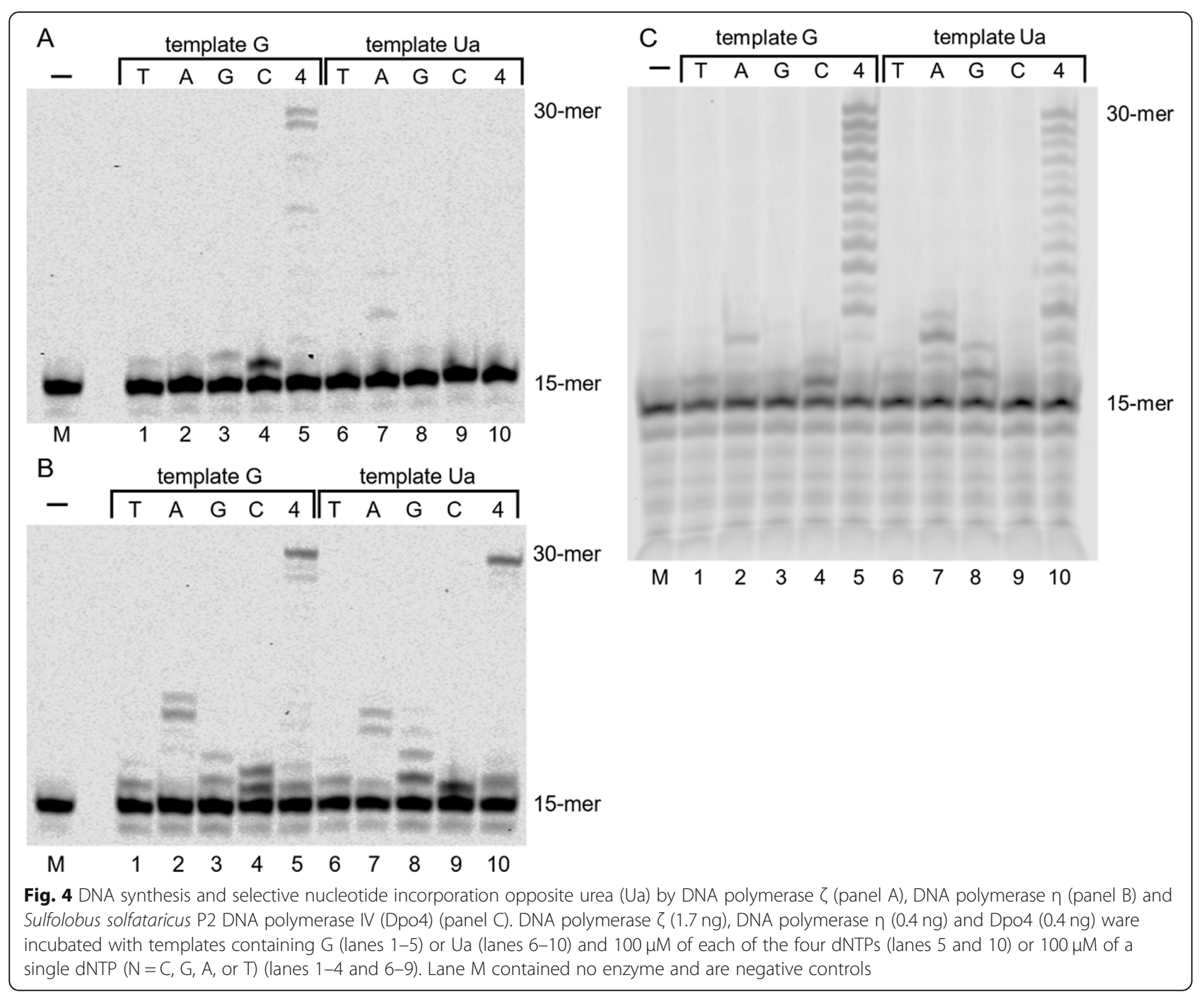

in translesion synthesis across Ua. Moreover, DNA polymerases $\delta$ and $\varepsilon$ are involved in lagging and leading strand synthesis $[33,34]$. Unlike DNA polymerase $\alpha$, DNA polymerases $\delta$ and $\varepsilon$ have $3^{\prime} \rightarrow 5^{\prime}$ exonuclease activity, and this activity is involved in the fidelity mechanisms of proofreading, mismatch repair, and Okazaki fragment maturation. However, DNA polymerases $\delta$ and $\varepsilon$ did not elongate the primer up to full-length across Ua, and produced degraded products of these primers (Fig. 3). Therefore, Ua is a lesion that strongly inhibits elongation by DNA polymerases $\delta$ and $\varepsilon$.

DNA polymerase $\zeta$ plays a critical role in an errorprone lesion bypass pathway [35-37]. We previously reported that the elongation efficiency to full-length beyond 2,2,4-triamino-5 $(2 H)$-oxazolone $(\mathrm{Oz})$ using DNA polymerase $\zeta$ was approximately the same as that of natural DNA [29]. Analysis of nucleotide selectivity shows that DNA polymerase $\zeta$ predominantly inserted mainly dATP opposite Ua but did not elongate the primer up to full-length across Ua (Fig. 4A). These results show that Ua has an inhibitory effect on DNA polymerase $\zeta$.

DNA polymerase $\eta$ can efficiently and accurately extend the primer beyond the cyclobutane pyrimidine dimer [38], as well as moderately elongate the primer to full length across $\mathrm{Oz}$ [39]. The present results show that DNA polymerase $\eta$ incorporated each of the four dNTPs opposite Ua, and only dGTP incorporation was increased opposite Ua compared with guanine (Fig. 4B). In addition, full-length extension across Ua was detected (Fig. 4B). Many previous reports showed that DNA polymerase $\eta$ elongated primers across many DNA lesions [38-43]. Similarly, DNA polymerase $\eta$ elongated the primer across Ua.

Dpo4 is a thermostable translesion synthesis polymerase and elongated the primer to full-length across $\mathrm{Ua}$ (Fig. 4C, lane 10). In addition, Dpo4 inserted dATP and dGTP opposite Ua to almost the same degree (Fig. 4C, lanes 6-9). In a previous report [44], Dpo4 inserted 

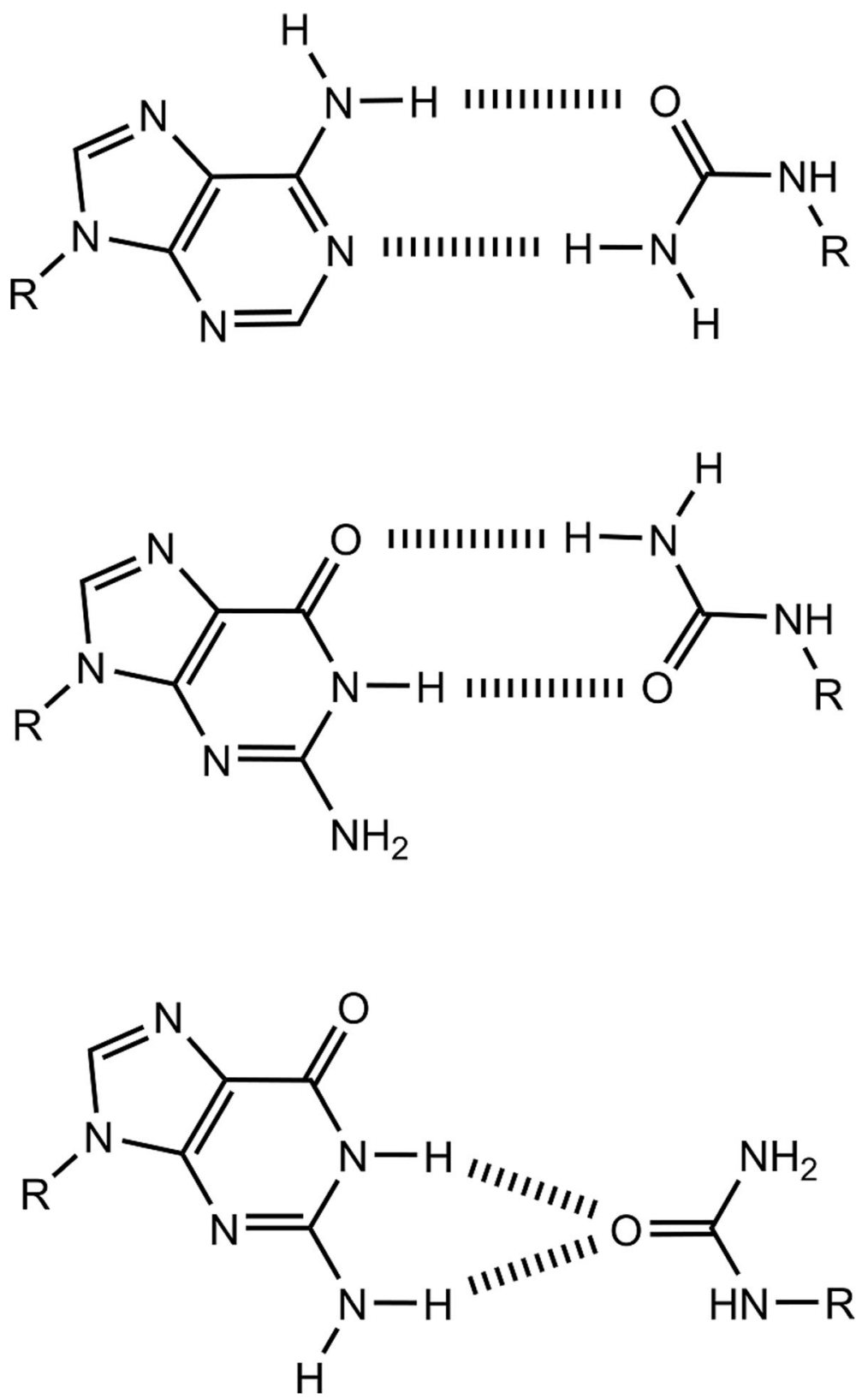

Fig. 5 Possible urea (Ua):A and Ua:G base pairs obtained from molecular dynamics simulations [45]

dATP opposite an abasic site more efficiently than dGTP. This difference may be attributed to forming base pairs via hydrogen bonds, as shown in Fig. 5 [45].

\section{Conclusion}

DNA polymerases $\alpha, \delta, \zeta$, and $\mathrm{Kf}^{\mathrm{exo}}{ }^{-}$predominantly inserted dATP opposite Ua, whereas DNA polymerase $\eta$ inserted dCTP, dGTP, dATP and dTTP. DNA polymerases $\beta$ and $\varepsilon$ were blocked by Ua, whereas polymerase $\alpha$ and $\mathrm{Kf} \mathrm{exo}^{-}$slightly elongated the primer to full-length across Ua. Elongation by DNA polymerases $\delta$ and $\zeta$ stopped after dATP was inserted opposite Ua.
Surprisingly, DNA polymerase $\eta$ and Dpo4 expanded the primer to full-length across Ua, similar to across guanine. Therefore, the stalling of DNA replication caused by the generation of Ua can be avoided using DNA polymerase $\eta$ and Dpo4. In the future, reactions of other DNA polymerases and templates containing Ua will be investigated.

\section{Abbreviations}

Ua: Urea; Kf: Klenow fragment; Dpo4: Sulfolobus solfataricus P2 DNA Polymerase IV; 30-merUa: 30-mer DNA template containing Ua; 6-merUa: 6mer oligonucleotide containing Ua; Oxa: Oxaluric acid; BSA: Bovine serum albumin; Oz: 2,2,4-triamino-5(2H)-oxazolone 


\section{Supplementary Information}

The online version contains supplementary material available at https://doi. org/10.1186/s41021-022-00236-3.

Additional file 1: Fig. S1. Construction of the 30-merUa. Two products (30-merUa1 and 30-merUa2) were obtained (Materials and methods). However, these two products equilibrate with each other and thus could not be isolated separately. In a previous report [7], Dubey, et al. revealed that Ua comprises the $a$ - and $\beta$-anomers. The mixture of the two products $\left(\mathrm{C}_{289} \mathrm{H}_{370} \mathrm{~N}_{103} \mathrm{O}_{176} \mathrm{P}_{29}\right)$ was confirmed by ESI-MS (m/z 9000.727) and then was used as 30-merUa in our experiment.

Additional file 2: Fig. S2. DNA synthesis across urea (Ua) by $\mathrm{Kf} \mathrm{exO}^{-}$. DNA synthesis in Fig. $\mathbf{S 2}$ was conducted under the same condition as in Fig. 2C. Kf exo- $(75 \mu \mathrm{U})$ was incubated with templates containing $\mathrm{G}$ (lane 3) or Ua (lane 4) and $100 \mu \mathrm{M}$ of each of the four dNTPs (lanes 1-4). Lanes 1 and 2 contained no enzyme and are negative controls. The background darkness of panel $A$ is adjusted in Panel B. Fig. S3. DNA synthesis across urea ( $\mathrm{Ua}$ ) by DNA polymerase $\eta$. DNA synthesis in Fig. S3 was conducted under the same condition as in Fig. 4B. DNA polymerase $\eta(0.4 \mathrm{ng})$ was incubated with templates containing $\mathrm{G}$ (lane 2) or Ua (lane 4) and $100 \mu \mathrm{M}$ of each of the four dNTPs (lanes 1, 2, 4 and 5). Lanes 1 and 5 contained no enzyme and are negative controls. The sample in lane 3 was a mixture of the samples in lanes 2 and 4.

\section{Acknowledgements}

We would like to thank Forte, Inc. (Tokyo) for their English language editing services.

\section{Authors' contributions}

Taishu Kawada, Kyousuke Tokorodani, Ryuto Anabuki and Kazuaki Ohara performed experimental work. Katsuhito Kino designed the research. Taishu Kawada, Katsuhito Kino, Masayuki Morikawa, Takanobu Kobayashi, Takayuki Ohshima and Hiroshi Miyazawa wrote the manuscript. All authors have read and approved the final manuscript.

\section{Funding}

Our research is supported by JSPS KAKENHI 17 K00558.

\section{Availability of data and materials}

All data generated during this study are included in this published article.

\section{Declarations}

Ethics approval and consent to participate

Not applicable.

\section{Consent for publication}

Not applicable.

\section{Competing interests}

The author declares that he has no competing interest related to this report.

\section{Author details}

'Kagawa School of Pharmaceutical Sciences, Tokushima Bunri University, 1314-1 Shido, Sanuki, Kagawa 769-2193, Japan. ${ }^{2}$ Faculty of Science and Engineering, Tokushima Bunri University, 1314-1 Shido, Sanuki, Kagawa 769-2193, Japan.

Received: 26 August 2021 Accepted: 1 February 2022

Published online: 15 February 2022

\section{References}

1. Teoule R, Bert C, Bonicel A. Thymine fragment damage retained in the DNA polynucleotide chain after gamma irradiation in aerated solutions. II Radiat Res. 1977;72(2):190-200. https://doi.org/10.2307/3574690.

2. Jensen WE, Jones AS, Ross GW. Glycosylureas. Part II. The synthesis and properties of 2-deoxy-D-ribosylureas. J Chem Soc. 1965;451:2463-5. https:// doi.org/10.1039/jr9650002463.

3. Breimer $L$, Lindahl T. A DNA glycosylase from Escherichia coli that releases free urea from a polydeoxyribonucleotide containing fragments of base residues. Nucleic Acids Res. 1980;8(24):6199-211. https://doi.org/10.1093/na r/8.24.6199.

4. Ide H, Kow YW, Wallace SS. Thymine glycols and urea residues in M13 DNA constitute replicative blocks in vitro. Nucleic Acids Res. 1985;13(22):8035-52. https://doi.org/10.1093/nar/13.22.8035.

5. Kow YW, Wallace SS. Exonuclease III recognizes urea residues in oxidized DNA. Proc Natl Acad Sci U S A. 1985;82(24):8354-8. https://doi.org/10.1073/ pnas.82.24.8354

6. Guy A, Ahmad S, Téoule R. Insertion of the fragile 2'-deoxyribosylurea residue into oligodeoxynucleotides. Tetrahedron Lett. 1990;31(40):5745-8. https://doi.org/10.1016/S0040-4039(00)97947-4.

7. Dubey I, Pratviel G, Robert A, Meunier B. Convenient method for the preparation of 2'-deoxyribosylurea by thymidine oxidation and NMR study of both anomers. Nucleosides Nucleotides Nucleic Acids. 2001;20(8):146371. https://doi.org/10.1081/NCN-100105241.

8. Hosford ME, Muller JG, Burrows CJ. Spermine participates in oxidative damage of guanosine and 8-oxoguanosine leading to deoxyribosylurea formation. J Am Chem Soc. 2004;126(31):9540-1. https://doi.org/10.1021/ja 047981q.

9. Henderson PT, Neeley WL, Delaney JC, Gu F, Niles JC, Hah SS, et al. Urea lesion formation in DNA as a consequence of 7,8-dihydro-8oxoguanine oxidation and hydrolysis provides a potent source of point mutations. Chem Res Toxicol. 2005;18(1):12-8. https://doi.org/10.1021/ tx049757k.

10. Katcher HL, Wallace SS. Characterization of the Escherichia coli X-ray endonuclease, endonuclease III. Biochemistry. 1983;22(17):4071-81. https:// doi.org/10.1021/bi00286a013.

11. Breimer LH. Urea-DNA glycosylase in mammalian cells. Biochemistry. 1983; 22(18):4192-7. https://doi.org/10.1021/bi00287a005.

12. Breimer $L H$, Lindahl T. DNA glycosylase activities for thymine residues damaged by ring saturation, fragmentation, or ring contraction are functions of endonuclease III in Escherichia coli. J Biol Chem. 1984;259(9): 5543-8. https://doi.org/10.1016/S0021-9258(18)91047-1.

13. Jorgensen TJ, Kow YW, Wallace SS, Henner WD. Mechanism of action of Micrococcus luteus y-endonuclease. Biochemistry. 1987;26(20):6436-43. https://doi.org/10.1021/bi00394a021.

14. Kow YW, Wallace SS. Mechanism of action of Escherichia coli endonuclease III. Biochemistry. 1987;26(25):8200-6. https://doi.org/10.1021/bi00399a027.

15. Kow YW. Mechanism of action of Escherichia coli exonuclease III. Biochemistry. 1989:28(8):3280-7. https://doi.org/10.1021/bi00434a024.

16. Melamede RJ, Hatahet Z, Kow YW, Ide H, Wallace SS. Isolation and characterization of endonuclease VIII from Escherichia coli. Biochemistry. 1994;33(5):1255-64. https://doi.org/10.1021/bi00171a028.

17. Yao M, Hatahet Z, Melamede RJ, Kow YW. Purification and characterization of a novel deoxyinosine-specific enzyme, deoxyinosine 3' endonuclease, from Escherichia coli. J Biol Chem. 1994;269(23):16260-8. https://doi.org/10.1 016/S0021-9258(17)34002-4

18. Roldán-Arjona T, Anselmino C, Lindahl T. Molecular cloning and functional analysis of a Schizosaccharomyces pombe homologue of Escherichia coli endonuclease III. Nucleic Acids Res. 1996;24(17):3307-12. https://doi.org/10.1 093/nar/24.17.3307

19. Aspinwall R, Rothwell DG, Roldan-Arjona T, Anselmino C, Ward CJ, Cheadle JP, et al. Cloning and characterization of a functional human homolog of Escherichia coli endonuclease III. Proc Natl Acad Sci U S A. 1997;94(1):109-14. https://doi.org/10.1073/pnas.94.1.109.

20. Reardon JT, Bessho T, Kung HC, Bolton PH, Sancar A. In vitro repair of oxidative DNA damage by human nucleotide excision repair system: possible explanation for neurodegeneration in xeroderma pigmentosum patients. Proc Natl Acad Sci U S A. 1997;94(17):9463-8. https://doi.org/10.1 073/pnas.94.17.9463.

21. You HJ, Swanson RL, Harrington C, Corbett AH, Jinks-Robertson S, Sentürker $\mathrm{S}$, et al. Saccharomyces cerevisiae Ntg1p and Ntg2p: broad specificity Nglycosylases for the repair of oxidative DNA damage in the nucleus and mitochondria. Biochemistry. 1999;38(35):11298-306. https://doi.org/10.1021/ bi991121i.

22. Asagoshi $\mathrm{K}$, Odawara $\mathrm{H}$, Nakano $\mathrm{H}$, Miyano $T$, Terato $H$, Ohyama $Y$, et al. Comparison of substrate specificities of Escherichia coli endonuclease III and its mouse homologue (mNTH1) using defined oligonucleotide substrates. Biochemistry. 2000;39(37):11389-98. https://doi.org/10.1021/bi0004221.

23. Ide H. DNA substrates containing defined oxidative base lesions and their application to study substrate specificities of base excision repair enzymes. 
Prog Nucleic Acid Res Mol Biol. 2001;68:207-21. https://doi.org/10.1016/ S0079-6603(01)68101-7.

24. Redrejo-Rodríguez M, Saint-Pierre C, Couve S, Mazouzi A, Ishchenko AA, Gasparutto D, et al. New insights in the removal of the hydantoins, oxidation product of pyrimidines, via the base excision and nucleotide incision repair pathways. PLoS One. 2011;6(7):e21039. https://doi.org/10.13 71/journal.pone.0021039.

25. Ide H, Petrullo LA, Hatahet Z, Wallace SS. Processing of DNA base damage by DNA polymerases. Dihydrothymine and $\beta$-ureidoisobutyric acid as models for instructive and noninstructive lesions. J Biol Chem. 1991;266(3): 1469-77. https://doi.org/10.1016/50021-9258(18)52318-8.

26. Evans J, Maccabee M, Hatahet Z, Courcelle J, Bockrath R, Ide H, et al. Thymine ring saturation and fragmentation products: lesion bypass, misinsertion and implications for mutagenesis. Mutat Res. 1993;299(3-4): 147-56. https://doi.org/10.1016/0165-1218(93)90092-R.

27. Hayes RC, LeClerc JE. Sequence dependence for bypass of thymine glycols in DNA by DNA polymerase I. Nucleic Acids Res. 1986;14(2):1045-61. https:// doi.org/10.1093/nar/14.2.1045.

28. McNulty JM, Jerkovic B, Bolton PH, Basu AK. Replication inhibition and miscoding properties of DNA templates containing a site-specific cisthymine glycol or urea residue. Chem Res Toxicol. 1998;11(6):666-73. https://doi.org/10.1021/tx970225w.

29. Suzuki M, Kino K, Kawada T, Morikawa M, Kobayashi T, Miyazawa H. Analysis of nucleotide insertion opposite 2,2,4-triamino-5(2H)-oxazolone by eukaryotic B- and Y-family DNA polymerases. Chem Res Toxicol. 2015;28(6): 1307-16. https://doi.org/10.1021/acs.chemrestox.5b00114.

30. Suzuki M, Ohtsuki K, Kino K, Kobayashi T, Morikawa M, Kobayashi T, et al. Effects of stability of base pairs containing an oxazolone on DNA elongation. J Nucleic Acids. 2014;178350:1-9. https://doi.org/10.1155/2014/1 78350.

31. Hamatake RK, Hasegawa H, Clark AB, Bebenek K, Kunkel TA, Sugino A. Purification and characterization of DNA polymerase II from the yeast Saccharomyces cerevisiae. Identification of the catalytic core and a possible holoenzyme form of the enzyme. J Biol Chem. 1990;265(7):4072-83. https:// doi.org/10.1016/50021-9258(19)39704-2.

32. Kino K, Morikawa M, Kobayashi T, Kobayashi T, Komori R, Sei Y, et al. The oxidation of 8-oxo-7,8-dihydroguanine by iodine. Bioorg Med Chem Lett. 2010;20(12):3818-20. https://doi.org/10.1016/j.bmcl.2010.04.032

33. Nick McElhinny SA, Gordenin DA, Stith CM, Burgers PMJ, Kunkel TA. Division of labor at the eukaryotic replication fork. Mol Cell. 2008;30(2):137-44. https://doi.org/10.1016/.jmolcel.2008.02.022.

34. Pursell ZF, IsOz I, Lundström EB, Johansson E, Kunkel TA. Yeast DNA polymerase $\varepsilon$ participates in leading-strand DNA replication. Science. 2007; 317(5834):127-30. https://doi.org/10.1126/science.1144067.

35. Zhu F, Zhang M. DNA polymerase Z: new insight into eukaryotic mutagenesis and mammalian embryonic development. World J Gastroenterol. 2003;9(6):1165-9. https://doi.org/10.3748/wjg.v9.i6.1165.

36. Lawrence CW. Cellular roles of DNA polymerase $\zeta$ and Rev1 protein. DNA Repair. 2002;1 (6):425-35. https://doi.org/10.1016/S1568-7864(02)00038-1.

37. Lawrence CW. Cellular functions of DNA polymerase $\zeta$ and Rev1 protein. Adv Protein Chem. 2004;69:167-203. https://doi.org/10.1016/S0065-3233(04 169006-1.

38. Masutani $C$, Kusumoto R, Iwai S, Hanaoka F. Mechanisms of accurate translesion synthesis by human DNA polymerase $\eta$. EMBO J. 2000;19(12): 3100-9. https://doi.org/10.1093/emboj/19.12.3100.

39. Kino K, Ito N, Sugasawa K, Sugiyama H, Hanaoka F. Translesion synthesis by human DNA polymerase $\eta$ across oxidative products of guanine. Nucleic Acids Symp Ser. 2004;48(1):171-2. https://doi.org/10.1093/nass/48.1.171.

40. Cho S-H, Guengerich FP. Replication past the butadiene diepoxide-derived DNA adduct $S$-[4-( $\left(N^{6}\right.$-deoxyadenosinyl)-2,3-dihydroxybutyl]glutathione by DNA polymerases. Chem Res Toxicol. 2013;26(6):1005-13. https://doi.org/1 $0.1021 / \mathrm{t} \times 400145 \mathrm{e}$

41. Kotapati S, Maddukuri L, Wickramaratne S, Seneviratne U, Goggin M, Pence $M G$, et al. Translesion snthesis across $1, N^{6}-(2-$ Hydroxy-3-

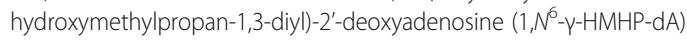
adducts by human and archebacterial DNA polymerases. J Biol Chem. 2012; 287(46):38800-11. https://doi.org/10.1074/jbc.M112.396788.

42. Kokoska RJ, McCulloch SD, Kunkel TA. The efficiency and specificity of apurinic/apyrimidinic site bypass by human DNA polymerase $\eta$ and Sulfolobus solfataricus Dpo4. J Biol Chem. 2003;278(50):50537-45. https://doi. org/10.1074/jbc.M308515200.
43. Njuma OJ, Su Y, Guengerich FP. The abundant DNA adduct $N^{\top}$-methyl deoxyguanosine contributes to miscoding during replication by human DNA polymerase $\eta$. J Biol Chem. 2019;298(26):10253-65. https://doi.org/10.1 074/jbc.RA119.008986.

44. Boudsocq F, Iwai S, Hanaoka F, Woodgate R. Sulfolobus solfataricus P2 DNA polymerase IV (Dpo4) an archaeal DinB-like DNA polymerase with lesionbypass akin to eukaryotic poln. Nucleic Acids Res. 2001;29(22):4607-16. https://doi.org/10.1093/nar/29.22.4607.

45. Suresh G, Padhi S, Patil I, Priyakumar UD. Urea mimics nucleobases by preserving the helical integrity of B-DNA duplexes via hydrogen bonding and stacking interactions. Biochemistry. 2016;55(40):5653-64. https://doi. org/10.1021/acs.biochem.6b00309.

\section{Publisher's Note}

Springer Nature remains neutral with regard to jurisdictional claims in published maps and institutional affiliations.

\section{Ready to submit your research? Choose BMC and benefit from:}

- fast, convenient online submission

- thorough peer review by experienced researchers in your field

- rapid publication on acceptance

- support for research data, including large and complex data types

- gold Open Access which fosters wider collaboration and increased citations

- maximum visibility for your research: over $100 \mathrm{M}$ website views per year

At BMC, research is always in progress.

Learn more biomedcentral.com/submissions 